\title{
A history of Graves and St. John's
}

\author{
David L. Williams ${ }^{1}$
}

Received: 18 September 2018 / Accepted: 18 September 2018 / Published online: 2 November 2018

(c) The Royal College of Ophthalmologists 2018

Robert Graves (1796-1853), the eminent Irish surgeon is best known for his eponymous exophthalmic goitre. Medical history also relates that he was arrested as a spy while travelling in Austria, travelled and sketched with J.M.W. Turner and saved a ship and its mutinous crew by taking command in a violent storm [1]. He is even said to have invented the second hand on watches although truth be told he merely promoted the use of the pulse watch in his lectures in clinical medicine of 1864 [2], the timepiece having originated with Sir John Floyer in 1707 [3]. Indeed Graves' 1835 description of three women with goitre and palpitations during his lectures at Meath hospital in 1825 [4] to which a further patient also with exophthalmos, was added by Williams Stokes, was similarly not the first. Caleb Parry (1755-1822) noted one patient developing goitre and palpitations post-partum and another showing the symptoms after stress, both recognised predisposing factors in the disease [5]. These observations, although earlier than those of Graves, were only published by his son after his death. Before them, in 1802, Giuseppe Flajani the Italian physician, had documented goitre and cardiac palpitations but without exophthalmos [6] while Carl von Basedow from Murseburg, Germany reported a patient with goitre, exophthalmos and tachycardia in 1840 [7]. The condition itself of course existed before any of these descriptions were published. At the front gate of St. John's, where the Cambridge Ophthalmic Symposium is held, stares out a gentleman with a clear case of Graves' ophthalmopathy (Fig. 1). Sadly, we know nothing of him, but his face must have been carved between 1511 when the college was founded and 1516 when first court of the college was completed. Not, it has to be said, that he is the first case of
Graves ophthalmopathy recorded, though quite possibly the first one set in stone! Zayn al-Din Sayyed Isma'il ibn Husayn Gorgani (1040-1136) recorded a patient with goitre, exophthalmos and palpitations in his classic medical encyclopaedia the Thesaurus of the Shah of Khwarazm as far back as 1110 [8].

\section{Compliance with ethical standards}

Conflict of interest The authors declare that they have no conflict of interest.

\section{References}

1. Ellis H. Robert Graves: 1796-1852. Br J Hosp Med (Lond). 2006;67:313.

2. Graves RJ. Clinical Lectures on the Practice of Medicine, London, New Sydenham Society. London: Lecture IV: The Pulse; 1864. New Sydenham Society, 1864. Lecture IV: The Pulse.

3. Floyer SJ. The Physician's Pulse Watch; or, an essay to explain the old art of feeling the pulse and to improve it by the help of a pulsewatch, Vol. I. London: S. Smith and B. Walford; 1707.

4. Graves RJ. Clinical lectures delivered at the Meath Hospital during the session of 1834-5. Lecture XII. Lond Med Surg J. 1835;7:513.

5. Parry $\mathrm{CH}$. Collections from the unpublished medical writings, London. Underwoods. 1825;2:110.

6. Flajani G. Sopra un tumor freddo nell'anterior parte del collo broncocele (Osservazione LXVII). Collezione d'osservazioni e reflessioni di Chir, Rome, Milano, A Ripa Press Lino Conte. 1802;3:270-3.

7. Basedow von LA. Exophthalmus durch hypert rophie des zellgewebes in der augenhole. Wochenschrift fur die Gesammte Heilkunde. 1840;13:197.

8. Nabipour I. Clinical endocrinology in the islamic civilization in Iran. Int J Endocrinol Metab. 2003;1:43-45.
David L. Williams

dlw33@cam.ac.uk

1 St John's College, University of Cambridge, St John's Street, Cambridge, UK 


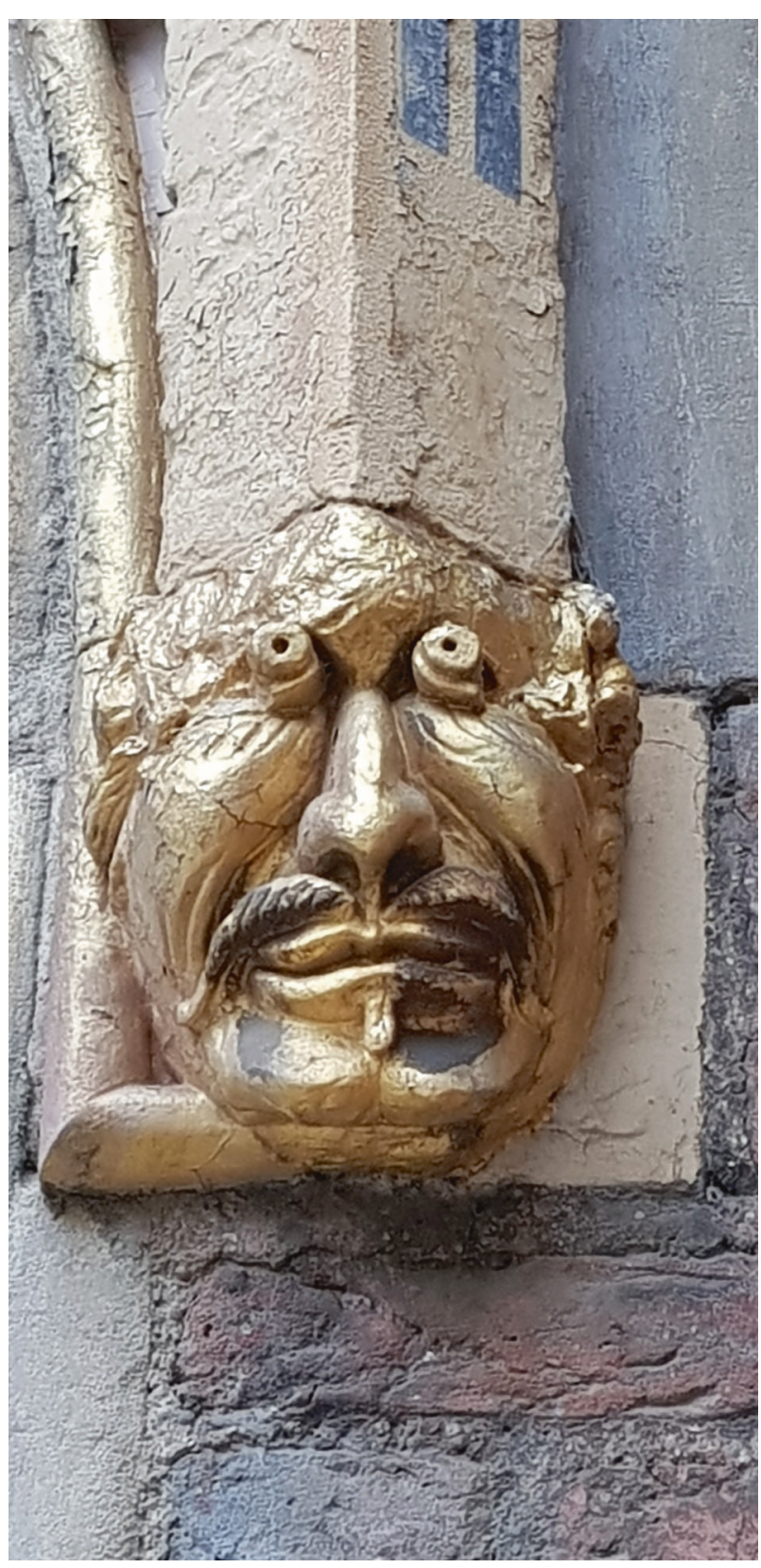

Fig. 1 Carving on the front gate of St John's College, Cambridge 